\title{
Impact of Work Hour on Employee Social Wellbeing in Northern Ireland
}

\author{
Mohammed Awad Alshahrani, \\ Lecturer of Business Administration \\ College of Business, King Khalid University, Saudi Arabia
}

Doi:10.19044/esj.2019.v15n19p99 ～URL:http://dx.doi.org/10.19044/esj.2019.v15n19p99

\begin{abstract}
This paper aims to explore the relationship that exists between the amount of hour's employees in Northern Ireland, work per week, and their social wellbeing represented by the level of happiness and Health status. This study made use of secondary data adapted from the 2009 Northern Ireland Life and Times Survey (NILT). Also, the study provides an analytic account of factors that determine the number of hours spent at work. The paper indicates that in Northern Ireland, there is no significant correlation between the amount of hours employee spent at work and their social wellbeing. Also, the study found that other factors such as: care for someone at home, sex, employed or self-employed, employment status, thinking about work, and socio-economic group significantly predicts the amount of time an employee in Northern Ireland spends at work. The study concluded that the relationship between work hour and employee social wellbeing varies across countries and cultures.
\end{abstract}

Keywords: Work hour per week, Social wellbeing, Northern Ireland

\section{Introduction}

Years of accrued research evidence shows that vital human needs are met through employment. These are mostly deemed to consist of real economic resources and security, improving life skills and one's sense of worth, and gaining social interactions and admiration from contemporaries. The satisfaction of these needs is significant for individuals but similarly, on a broader level, for the health and wellbeing of society (O'Toole \& Lawler, 2006).

In the last century, scholars forecasted that the future working time would reduce due to improvements in productivity and debated that working weeks of the order of 15 hours per week may be characteristic in the early $21 \mathrm{st}$ century (Dower, 1965; Handy, 1984). Thus, reduced working time is 
perceived as a step in the direction of a perfect "leisure society," even though several observers cautioned of the moral or social consequences that may arise from expanded non-working time (e.g., Veal, 2009). Despite this, others envisioned that paid work might be substituted with self-production (Gershuny, 1978; Gorz, 1999) or voluntary work (Rifkin, 1995) instead of leisure.

Paid working time reduced significantly in the first half of the $20^{\text {th }}$ century, the reductions after, were lesser. But some researcher state that the trend may have reversed (Schor, 1992). Also, the fraction of the working people has increased, coupled with a rise in the number of employed women. In the last few years, the number of elderly workers has also increased. In human history, work has generally continued to play a vital part in people's life experiences. What has possibly changed in the last twenty years is that even though the mean working hours have remained somewhat steady, there has been an inclination in the direction of more varied work schedules, with a rise in both long-hours working and part-time jobs.

According to Vander (2003), a person's working hours determines biological as well as social patterns, including sleeping, recovery from injuries or diseases, and body hormones. The daily rhythms of the individual are also significantly affected by the organization of working hours. It affects lifestyle, for instance, the potentials of engaging in physical activities and eating a regular diet (Ezoe \& Morimoto, 1994; Yamada et al., 2001). Some of the concerns, mainly relating to health, are well-known and well-documented in research (van der Hulst, 2003; Caruso et al., 2004; Tucker, 2006). However, no comprehensive depiction of social concerns has been found in the research literature (Barnett, 1998; Geurts \& Demerouti, 2003).

In numerous ways, worktime schedules impact energy and time spent with the family. It also goes further to affect an individual's voluntary ventures and leisure times. Research targeting these issues has greatly increased over the past ten years. Extended periods in the workplace (Jansen et al., 2004), overtime work (Voydanoff, 2004), and shift work (Fenwick and Tausig, 2001) are closely linked to diminished work like balance. Further study by (Hill and colleagues, 2004) found out that a change in one's daily schedule and overtime results in a better life balance are associated with better work-life balance.

The growing diversity of working hours has created attention on the influence of irregular working hours on a person's wellbeing. A closer look into the issue has elicited fears of the detrimental effect that extended working hours cause people (Bunting, 2004; Schor, 1992). Consequently, this article seeks to investigate the relationship between the social wellbeing of workers in Northern Ireland and work hours per week as well as further exploring factors that determine the work hour per week. 
Based on the identified gap in research, the following research questions were put forward to be answered in this report; Does work hour per week correlates significantly with employee happiness and health in Northern Ireland? What factors significantly predict employee work hour per week? For this study, only two hypotheses were formulated, and they are stated as follows; $\mathrm{H}_{\mathrm{o}}$ : There is no significant relationship between work hour per week and worker happiness. $\mathrm{H}_{\mathrm{o}}$ : There is no significant relationship between work hour per week and worker health.

\section{Literature \& Theoretical Review}

For many reasons including collective progressive pressure from labor unions, improved efficiency and productivity, and worker-friendly legislation has led to the decrease in the official work hours spent at the workplace (Virtanen and Kivimaki, 2018). Nevertheless, in today's workplace, the working hours are no longer limited to the time that is spent at the office because work can be performed remotely, at any time and any place. Most opinions believe that the perceived insufficiency of time to perform work tasks may be due to the increased work demands that does not allow work to be done within the official 7 to 8-hour work day.

There have been many studies on the effect of long working hours to the social wellbeing of the worker, which shows the relationship between long work hours and social wellbeing, Similar to the study of psychological stress due to the impact of long working hours on workers (Yavas et al., 2008). Also, the effect on sleep and mental health when workers work long hours (Afonso et al., 2017); the effects of extended hours on the health of shift workers (Harrington, 2001). But according to Artazcoz et al. (2018), the conclusions of these and other studies have been mainly contradictory. These studies define long working hours as working in excess of between 40 to 55 hours per week, and in some extreme cases in Asia where they work for upwards 60 hours per week with a commonly practiced system referred to as 996 (from 9:00 am to 9:00 pm, 6 times a week) (Virtanen \& Kivimaki, 2018). This relationship between long work hours and social wellbeing is multifaceted and not understood easily because other factors affect it (Ganster et al., 2016; Artazcoz et al., 2018).

Furthermore, even though the quality of the job has been pinpointed as mediating factor in this relationship, there are almost no studies to demonstrate this (Beckers et al., 2004; Johnson \& Lipscomb, 2006). Another mediating factor in need of further research is the organizational context on the effects of long working hours and employee health (Caruso et al., 2006). Other variables that are related to long working hours include working in two jobs or more, working split or shift, irregular or on-call duties, and mandatory overtime (Grosch et al., 2006). 
Compulsory overtime also has the deleterious effect of restricting taking on other jobs or hobbies, poor opinion about the employment and adverse relationship with the management (Golden et al., 2005). Also, Van Der Hulst \& Geurts (2001) concluded that in low motivated situations, involuntary overtime might lead to mental health issues, which may then suggest that when long working hours occur in poor quality jobs. However, it is considered a significant risk because of the health impact as compared to spending long work hours in professional and more rewarding careers (Beckers et al., 2004; Johnson \& Lipscomb, 2006; Artazcoz et al., 2018).

\section{Factors that Influence Work Hour}

Financial and family responsibilities are constant strains that have some clear influences on the relationship between lengthy hours at work and health. It has been observed that workers seeking to spend more time with family have a preference for shorter hours while those that have economic challenges will opt for more extended hours (Caruso et al., 2006). Hence, the choice has played a significant role in long working hours and social wellbeing (Pollert \& Charlwood, 2009). For instance, the workers who are the primary home providers will accept voluntary and involuntary forms of long work hours that are backed with compensation because they want to meet up with family obligations and debt. Also, the influence of bargaining power is a significant factor. When workers are vulnerable, situations of not belonging to a union, in temporary jobs, high rate of unemployment and receiving low wages, the workers are more likely to be coerced into putting in longer work hours (Stier \& Lewin-Epstein, 2003). The vulnerability has a root cause in poor employment and working conditions.

Furthermore, the work hour's decisions of workers may also receive motivation from external forces and not just individual, for example, culture, institution, the regulatory environment of the society which is correlated to the state of social welfare of employees (Abendroth, 2012). Thus, in regulated labor markets, collective agreements are very influential in determining the working hours while state statutory are a safety net for workers in ununionized workers. Family responsibilities typically restrain how long women usually work, which leads to men having more work hours in paid work environments. This pattern is presented in the results of Artazcoz et al. (2018), which emphasized that men work more hours than women in most countries.

Over the past two decades, various studies have shown the relationship of work-life, working long hours, and how its impacts on men and women alike (Kaushal \& Parmar, 2019). Women have continued to become as more active in today's workplace and take up roles that men traditionally used to hold (Kar et al., 2019). Women initially had the pressure to balance work and life because of the traditional role of men being breadwinners and women 
being homemakers, and therefore women came under considerable stress because of working long hours to strive in their careers and still be good mothers (Byrne, 2005). However, these days, the reverse has become the case as men want to do all these. Thus, the work-life balance phenomenon applies to both men and women.

Another significant driver towards the quest for achieving work-life balance may be that the new generation and younger workforce do not spend the same work hours as their parents, they want significant control over their work life, want a more significant role in determining their work schedules and what they can offer in the future (Kaushal \& Parmar, 2019). Therefore, work-life balance is when workers or individuals change things by their changing priorities, physical and psychological circumstances that are triggered by age, changes in technology, poor management and improving work conditions (Leslie et al., 2019). Hence, when there is a balance the employee benefits by having a sense of responsibility and ownership (Avgoustaki \& Frankor, 2019); having a better management-employee relationship and not bringing work issues home and home issues to work (Kaushal \& Parmar, 2019). On the other hand, the firm management will gain the advantage of a better-motivated workforce, a productive and less stressed pool of employees that feel they are valued, attract fresh quality talents \& retain old ones, increased productivity, reduced absenteeism, become known as a great place to work, reduce costs and maximize available labor (Kaushal \& Parmar, 2019; Kar et al., 2019; Leslie et al., 2019).

\section{Conflict Theory}

The conflict theory explains that the time spent at work affects social life. That conflict arises from the incompatibility of the individual's role at work and their social life. Frone et al. (1992) state that the work-social life conflict is not unidimensional as earlier research had shown but is rather bidimensional, because the work-life interferes with the social life and vice versa. Kelly et al. (2008) report that most research focused on the work-social life conflict among employees. This conflict between the relationship between a worker's social life and their work life can be time-based, strain-based, and behavior-based. It occurs when the time required for either work or social life interferes with the other, making it difficult to participate in an essential role. In other words, the competing requirements of time make the time-based conflict more prevalent. The time required to satisfy one's role (social- or work-based) is always in competition with the time meant for the other role, making it impossible to satisfy the time demands of either competing role. 


\section{Research Methods}

This study aims to explore the relationship between work hours per week, and some variables representing social wellbeing's such as employee health and employee happiness, and to determine factors that predict employee work hour. Thus, this section contains the type of data, the description of variables of interest, and all the steps taken to answer the research questions.

\section{Measure}

This study made use of secondary data adapted from the 2009 Northern Ireland Life and Times Survey (NILT). The data is cross-sectional, which involves randomly selected respondents across Northern Ireland. Table 1 below describes the variables analyzed in this study;

Table 1: Variable Description Table

\begin{tabular}{|c|c|}
\hline Variables & Description \\
\hline Sex of respondent & Male $=1$, Female $=2$ \\
\hline Socio Economic Group & $\begin{array}{l}\text { Professional }=1, \text { Managerial and } \\
\text { Technical }=2, \text { Skilled, non-manual }=3 \text {, } \\
\text { Skilled, manual }=4 \text {, Partly skilled }=5 \text {, } \\
\text { Unskilled Labor }=6 \text {, Never Worked }=7 \text {, } \\
\text { Full time student }=8\end{array}$ \\
\hline Employed or self-employed & An employee $=1$, self-employed $=2$ \\
\hline Care for someone in your home & Yes $=1, \mathrm{No}=2$ \\
\hline Thinking about work & $\begin{array}{l}\text { Very much }=1 \text {, To a large extent }=2, \text { to } \\
\text { some extent }=3 \text {, not at all }=4 \text {, Cant choose } \\
=5\end{array}$ \\
\hline Current employment status & $\begin{array}{l}\text { Worked last week }=1 \text {, Away from work } \\
\text { last week }=2 \text {, waiting to take up job }=3 \text {, } \\
\text { Looking for work }=4 \text {, sick }=5 \text {, } \\
\text { Economically Inactive }=6 \text {, Government } \\
\text { Training Scheme }=7 \text {, Refusal }=8 \text {, Don't } \\
\text { Know }=9\end{array}$ \\
\hline \multicolumn{2}{|l|}{ Work Hours per Week } \\
\hline Happiness & $\begin{array}{l}\text { Very Happy }=1 \text {, Fairly Happy }=2, \text { Not } \\
\text { very happy }=3 \text {, Not at all happy }=4 \text {, Can't } \\
\text { Choose }=5\end{array}$ \\
\hline \multicolumn{2}{|l|}{ Health } \\
\hline Marital status & $\begin{array}{l}\text { Single }=1, \text { Married }=2, \text { Civil Partner }=3, \\
\text { Married and separated }=4, \text { Divorced }=5, \\
\text { Widowed }=6, \text { Spontaneous }=7-9\end{array}$ \\
\hline \multicolumn{2}{|l|}{ Age } \\
\hline \multicolumn{2}{|l|}{ Income } \\
\hline Care for someone outside the home & Yes $=1, \mathrm{No}=2$ \\
\hline Partners number of work hours per week & \\
\hline
\end{tabular}




\section{Statistical Analysis}

Both descriptive and inferential statistics were used to answer the first research question in this study, which states that: Does work hour per week correlates significantly with employee happiness and employee health in Northern Ireland? Spearman's rho was used to correlate work hour per week to health and happiness. Furthermore, to provide an answer to the second research question which sought to identify the factors that predict work hour per week, a multiple linear regression (stepwise method) was utilized. The following variables were the independent variables; sex, respondent socioeconomic group, employment or self-employed, care for someone in your home, find yourself thinking about work, respondent current employment status, marital status, age, income, care for someone outside the home, respondent's employment status, partners number of hours worked per week.

\section{Data Analysis}

a. Descriptive Statistics

The most frequently observed category of Sex was "Female" ( $n=699$, $57 \%$ ). The most frequently observed category of Employment Status was "Worked last week" ( $n=616,50 \%)$. The most frequently observed category of "Socio-Economic Group" was Managerial and Technical ( $n=350,29 \%)$. Frequencies and percentages are presented in Table 2.

Table 2: Frequency Table for Nominal Variables

\begin{tabular}{|l|l|l|}
\hline Variable & $n$ & $\%$ \\
\hline Sex & & \\
\hline Male & 529 & 43.08 \\
\hline Female & 699 & 56.92 \\
\hline Missing & 0 & 0.00 \\
\hline Employment Status & & \\
\hline Worked last week & 616 & 50.16 \\
\hline Economically inactive & 518 & 42.18 \\
\hline Looking for work & 39 & 3.18 \\
\hline Away from work last week & 20 & 1.63 \\
\hline Not looking for work - sick & 32 & 2.61 \\
\hline Waiting to take up a job & 2 & 0.16 \\
\hline Government training scheme & 1 & 0.08 \\
\hline Missing & 0 & 0.00 \\
\hline Socio-Economic Group & & \\
\hline Skilled Non-Manual & 254 & 20.68 \\
\hline Managerial and Technical & 350 & 28.50 \\
\hline Skilled Manual & 208 & 16.94 \\
\hline & & \\
\hline & & \\
\hline
\end{tabular}




\begin{tabular}{|l|l|l|}
\hline Partly Skilled & 210 & 17.10 \\
\hline Professional & 48 & 3.91 \\
\hline Never worked & 68 & 5.54 \\
\hline Don't know & 1 & 0.08 \\
\hline Unskilled Manual & 65 & 5.29 \\
\hline Full-time students & 19 & 1.55 \\
\hline Missing & 5 & 0.41 \\
\hline
\end{tabular}

The observations for "Age" had an average of $48.96\left(S D=17.77, S E_{M}\right.$ $=0.51$, Min = 18.00, Max =95.00). The observations for "Hours Worked per Week" had an average of $36.42\left(S D=12.60, S E_{M}=0.37\right.$, Min = 3.00, Max = 99.00). Skewness and kurtosis were also calculated below.

Table 3: Summary Statistics Table for Age and Hours Worked per Week

\begin{tabular}{|l|l|l|l|l|l|l|}
\hline Variable & $M$ & $S D$ & $n$ & $S E_{M}$ & Skewness & Kurtosis \\
\hline Age & 48.96 & 17.77 & 1228 & 0.51 & 0.26 & -0.82 \\
\hline Hourswk/week & 36.42 & 12.60 & 1154 & 0.37 & 0.41 & 2.45 \\
\hline
\end{tabular}

b. Inferential Statistics

To answer the question; does work hour per week correlates significantly with employee happiness and employee health in Northern Ireland? A Spearman's correlation was used to test for association between work hours per week and health and happiness (both representing social wellbeing). Table 4 shows the correlation matrix.

Table 4: Spearman Correlation Coefficients

\begin{tabular}{|l|l|l|l|}
\hline Variable & 1 & 2 & 3 \\
\hline (1) Work Hours per Week & 1 & & \\
\hline (2) Happiness & 0.041 & 1 & \\
& $(\mathrm{p}=0.184)$ & & \\
\hline (3) Health & 0.037 & .360 & 1 \\
& $(\mathrm{p}=0.239)$ & $(\mathrm{p}=0.000)$ & \\
\hline
\end{tabular}

The result from the Spearman's correlation shows that there is no correlation between work hours per week and happiness $(r=0.041, p=0.184)$. Consequently, the null hypotheses were accepted. Also, no significant relationship between work hours per week and health $(\mathrm{r}=0.037, \mathrm{p}=0.239)$, thereby, accepting the null hypothesis and suggesting that there is no statistically significant correlation between the number of work hours per week and happiness, and health (both representing social wellbeing).

Furthermore, to answer the research question of what factors significantly predict employee work hour per week? A stepwise multiple regression was used with work hour per week as the dependent variable, and 
the following variables were entered as Independent variables; sex, respondent socio-economic group, employment or self-employed, care for someone in your home, find yourself thinking about work, respondent current employment status, marital status, age, income, care for someone outside the home, respondents employment status, partners number of hours worked per week. The results of the regression model were significant, $F(6,439)=22.92, p$ $<0.001, R^{2}=0.239$, indicating that approximately $23.9 \%$ of the variation in work hour per week is explainable by sex, respondent socio-economic group, employment or self-employed, care for someone in your home, find yourself thinking about work, respondent current employment status, marital status, age, income, care for someone outside the home, respondents employment status, partners number of hours worked per week. Thus, it can be inferred that the six independent variables are the factors that significantly determine employee work hour per week in Northern Ireland (Table 5).

Table 5: Regression Coefficient Table

\begin{tabular}{|l|c|c|c|c|c|}
\hline Variables & $\begin{array}{c}\text { Unstandardized } \\
\text { B }\end{array}$ & $\begin{array}{c}\text { Std. } \\
\text { Error }\end{array}$ & $\begin{array}{c}\text { Std. } \\
\text { Beta }\end{array}$ & $\mathrm{t}$ & $\mathrm{p}$ \\
\hline (Constant) & 39.51 & 4.772 & & 8.280 & 0.000 \\
\hline Sex of respondent & -9.00 & 1.010 & -0.384 & -8.903 & 0.000 \\
\hline Socio Economic Group & -1.18 & 0.383 & -0.131 & -3.079 & 0.002 \\
\hline Employed or self employed & 4.64 & 1.604 & 0.125 & 2.895 & 0.004 \\
\hline Care for someone in your home & 5.53 & 1.749 & 0.135 & 3.160 & 0.002 \\
\hline Thinking about work & -1.20 & 0.417 & -0.131 & -2.878 & 0.004 \\
\hline Current employment status & 0.69 & 0.244 & 0.130 & 2.841 & 0.005 \\
\hline
\end{tabular}

Work Hour per Week $=39.51-9($ Sex $)-1.18$ (Socio-Economic Group $)+4.64($ Employed or self-employed $)+5.53$ (Care for someone in your home $)-1.20$ (Thinking about work) +

0.69 (Current employment status) $+\mathrm{e}$

\section{Result and Discussion}

Turning first to the correlations, the findings of the study provide a counter-argument to what exists in the general themes in some existing literature that work hours correlates significantly to health and happiness variables. Consequently, this study affirms Artazcoz et al. (2018) conclusions, which suggests that the findings of these and other studies have been mainly contradictory. This study revealed that no statistically significant correlation exists between work hours per week and happiness $(r=0.041, p=0.184)$ and work hour per week and health $(\mathrm{r}=0.037, \mathrm{p}=0.239)$, which informs the conclusion that in Northern Ireland, the amount of time (Hours) put into work has nothing to do with the social wellbeing of workers.

Secondly, the findings from the analysis to determine the factors that predict work hour per week shows that gender predicted work hour per week, as a unit increase in the category of gender (male to a female) leads to a nine units decrease in work hour per week. This infers that the female gender work 
lesser than their male counterparts in Northern Ireland. Also, a unit increase in the category of the socio-economic group leads to a 1.18 units decrease in work hour per week, which infers that people lower in hierarchy professionally work more hours when compared to people with people high on the authority. Also, a one unit increase in the category of employed or self-employed leads to 4.64 units increases in work hour per week, which infers that self-employed respondents work more hours per week than employed respondents. Furthermore, a one unit increase in the variable care for someone at home (yes and no) leads to a 5.53 units increase in work hour per week, and this infers that respondents who don't have people to care for at home spent more hours at work per week. Also, a unit increase in the category of thinking about work leads to a 1.20 unit decrease in work hour per week. Lastly, a unit increase in the category of current employment status leads to a 0.69 units increase in work hour per week.

Lastly, as the study did not find a significant positive or negative relationship between employee work hour, health status and employee happiness, nothing can be suggested in the aspect of the policy implications of the study, however, it is expected that employee work-hour has to be flexible to ensure that employee wellbeing is accounted for, and by extension that employee are generally happy to drive productivity.

\section{Recommendations and Future Research Directions}

The methods used in the survey is, to some extent, flawed, in the sense that some of the variables were not captured appropriately. Variables such as happiness and health are latent variables which requires the use of psychosocial constructs for data collection, but in this study, it's been used as an observed variable. Also, a Structural Equation Model is recommended to analyze path relationships (moderator, mediator, and linear relationships) amongst the variables, and to test for model fit.

\section{References:}

1. Abendroth, K., van der Lippe, T., \& Maas, I. (2012) Social support and the working hours of employed mothers in Europe. The relevance of the state, the workplace, and the family. Social Science Research., 41, 581597.

2. Afonso, P., Fonseca, M., \& Pires, J. (2017) Impact of working hours on sleep and mental health. Occupational Medicine, 67(5), 377-382.

3. Artazcoz, L., Cortès-Franch, I., Escribà-Agüir, V., López, M., \& Benavides, F. (2018) Long working hours and job quality in Europe: Gender and welfare state differences. International Journal of Environmental Research and Public Health, 15(11), 2592. 
4. Avgoustaki, A., \& Frankort, W. (2019) Implications of work effort and discretion for Employee Well-Being and Career-Related Outcomes: An Integrative Assessment. ILR Review, 72(3), 636-661.

5. Beckers, G., Van Der Linden, D., Smulders, G., Kompier, J., Van Veldhoven, M., \& Van Yperen, N. (2004) Working overtime hours: Relations with fatigue, work motivation, and the quality of work. Journal of Occupational Environmental Medicine, 46, 1282-1289.

6. Byrne, U. (2005). Work-life balance. Business Information Review, 22(1), 53-59.

7. Carlson, S., Kacmar, M., Wayne, H., \& Grzywacz, H. (2006) Measuring the Positive Side of the Work-Family Interface: Development and Validation of a Work-Family Enrichment Scale. Journal of Vocational Behaviour, 68: 131-164

8. Caruso, C., Bushnell, T., Eggerth, D., Heitmann, A., Kojola, B., Newman, K., Rosa, R., Sauter, L., \& Vila, B. (2006) Long working hours, safety, and health: toward a national research agenda. American Journal of Industrial Medicine, 49, 930-942.

9. Clark, C. (2000) Work/family border theory: A new theory of work/family balance. Human Relations, 53: 747-770.

10. Dower, M. (1965) The Fourth Wave: The Challenge of Leisure. London: Civic Trust (reprinted from The Architect's Journal, 20 Jan.: 123-90).

11. Edwards, R., Rothbard, P. (2000) Mechanisms Linking Work and Family: Clarifying the Relationship between Work and Family Constructs. Academy of Management Review, 25 (1): 178-99.

12. Frone, R. (2003) Work-family Balance. In J C Quick \& L E Tetrick (eds), Handbook of Occupational Health Psychology. Washington, D.C: American Psychological Association. Pp 143-162.

13. Ganster, C., Rosen, C., \& Fisher, G. (2018) Long working hours and wellbeing: What we know, what we do not know, and what we need to know. Journal of Business and Psychology, (1), 25.

14. Gershuny, J. (1978) After Industrial Society? The Emerging Self-service Economy. London: Macmillan.

15. Golden, L., \& Wiens-Tuers, B. (2005) Mandatory overtime work in the United States: Who, Where, and what? Labor Studies Journal, 30, 1-25.

16. Gorz, A. (1999). Reclaiming Work: Beyond the Wage-based Society. Cambridge: Polity Press

17. Greenhaus, H., Collins, M., \& Shaw, D. (2003) The relation between work-family balance and quality of life. Journal of Vocational Behavior 63: 510-531.

18. Grosch, W., Caruso, C., Rosa, R., \& Sauter, L. (2006) Long hours of work in the U.S.: Associations with demographic and organizational 
characteristics, psychosocial working conditions, and health. American Journal of Industrial Medicine, 49, 943-952.

19. Grzywacz,G., \& Bass, L. (2003) Work, family and mental health: Testing different models of work-family fit. Journal of Marriage and Family, 65: $248-261$.

20. Handy, C. B. (1984) The Future of Work: A Guide to a Changing Society. Oxford: Blackwell.

21. Harrington, J. (2001). Health effects of shift work and extended hours of work. Occupational and Environmental Medicine, 58(1), 68-72.

22. Johnson, V., \& Lipscomb, J. (2006) Long working hours, occupational health, and the changing nature of work organization. American Journal of Industrial Medicine, 49, 921-929.

23. Kalliath, T., \& Brough, P. (2008) Work-Life Balance: A review of the meaning of the balance construct. Journal of Management \& Organization, 14(3), 323-327. doi: 10.5172/jmo.837.14.3.323

24. Kar, B., Panda, M. C., \& Pathak, M. D. (2019) Women's Work-Life Balance: Compensation is the Key. Journal of Management Research (09725814), 19(1), 29-40.

25. Kaushal, P., \& Parmar, J. S. (2019) Work-Life Balance and Its Relation to Demographic Factors: A Study of Police Personnel of Himachal Pradesh. Journal of Strategic Human Resource Management, 8(1), 1-12.

26. Kelly, L., Kossek, L., Hammer, B., Durham, M., Bray, J., Charmack, K., Murphy, L., \& Kaskubar, D. (2008) Getting there from Here: Research on the Effects of Work-Family Initiatives on Work-Family Conflict and Business Outcomes. An Academy of Management Annals, 2: 305-49.

27. Keyes, M., \& Lopez, S. (2002) Toward a science of mental health: Positive directions in diagnosis and interventions, in C. R. Snyder \& S. Lopez (Eds.), Handbook of Positive Psychology (pp. 45-59), Oxford University Press: New York, NY.

28. Leslie, M., King, B., \& Clair, A. (2019) Work-Life Ideologies: The Contextual Basis and Consequences of Beliefs About Work and Life. Academy of Management Review, 44(1), 72-98.

29. Noury, L., Gand, S., \& Sardas, C. (2017) 'Tackling the work-life balance challenge in professional service firms: The impact of projects, organizing, and service characteristics,' Journal of Professions \& Organization, 4(2), p. 149.

30. O'Toole, J. and Lawler, E. (2006) The New American Workplace. New York: Palgrave.

31. Pattu Meenakshi, S., Venkata Subrahmanyam, C., \& Ravichandran, K. (2013) The Importance of Work-Life-Balance. IOSR Journal of Business And Management, 14(3), 31 - 35. Retrieved from http://www.iosrjournals.org 
32. Pollert, A. (2005) The unorganized worker: The decline in collectivism and new hurdles to individual employment rights. Industrial Law Journal, $34,217-238$.

33. Rifkin, J. (1995) The End of Work: The Decline of the Global Labour Force and the Dawn of the Post-Market Era. New York: G. P. Putnam's Sons.

34. Schor, J. (1992) The Overworked American: the Unexpected Decline of Leisure. New York: Basic Books.

35. Stier, H., \& Lewin-Epstein, N. (2003) Time to Work: A Comparative Analysis of Preferences for Working Hours. Work Occupation, 30, 302326.

36. Teghe, D., \& Rendell, K. (2005) Social wellbeing: a literature review. School Of Social Work \& Welfare Studies. doi: 10.13140/RG.2.2.28891.26406

37. Van der Hulst, M. (2003) Long workhours and health. Scandinavian Journal of Work, Environment, and Health 29:171-188.

38. Van Der Hulst, M., \& Geurts, E. (2001) Associations between overtime and psychological health in high and low reward jobs. Work Stress, 15, 227-240.

39. Virtanen, M., \& Kivimaki, M. (2018). Long Working Hours and Risk of Cardiovascular Disease. Current Cardiology Reports, (11), 1.

40. Wayne, J., Musisca, N., \& Fleeson, W. (2004) Considering the Role of Personality in the Work-Family Experience: Relationship of the Big Five to Work-Family Conflict and Facilitation. Journal of Vocational Behaviour, 64: 108-130.

41. Yavas, U., Babakus, M., \& Karatepe. (2008) Attitudinal and Behavioral Consequences of Work-Family Conflict and Family-Work Conflict: Does Gender Matter? International Journal of Service Industry Manage., 19(1): 7-31. 